\title{
主要公共交通機関利用を想定した移動時間最小化による効率的拠点配置の試案

\author{
A PROPOSAL FOR THE OPTIMUM LOCATION OF HUBS BY MINIMIZING \\ TRAVEL TIME WITH MAIN PUBLIC TRANSPORT USAGE
}

\author{
島村 亮*1, 佐藤栄治*2, 鈴木達也*3, 野原康弘 ${ }^{* 4}$ \\ Ryo SHIMAMURA, Eiji SATOH, Tatsuya SUZUKI \\ and Yasuhiro NOHARA
}

\begin{abstract}
The purpose of this study is to reveal the optimum location of district hubs by minimizing the sum of residents' travel time with public transport usage in the study city. In Japan, there has been an effort to promote the change of an urban structure by combination of hubs and public transport's traffic axes. By comparing the current plan with the optimum location, the imbalance about the user populations of each hub are revealed in the current plan. In addition, the validity in location of 6 out of 16 district hubs in the current plan was demonstrated.
\end{abstract}

Keywords: Hub, Public transportation, Optimum location, Minisum model, Travel time, Residence-guided 拠点, 公共交通機関, 最適配置, ミニサム基準, 移動時間, 居住誘導

\section{1. 研究の背景と目的}

本稿では、拠点と公共交通軸の組合せによって将来的な都市構造 を定める地方都市を対象に、徒歩と公共交通機関利用による拠点 の移動を想定し、拠点配置の評価手法を示し、効率的な拠点配置に ついて検討することを目的とする。

\section{1 社会的背景}

利便性は住環境を示寸基本理念の一つである ${ }^{1)}$ 。特に、生活関連 施設や交通機関へのアクセスのしやすさ (以下、移動的利便性 /ア クセシビリティ）は重要な指標である。モータリゼーションの進展、 市街地の拡大によって自動車依存の都市構造を形成してきた我が国 の都市では、人口減少・少子高齢化により、生活関連施設へのアク セシビリティの観点から、利便性の継続的な担保に課題を抱えてい る。国立社会保障・人口問題研究調査による日本の将来推計人口 ${ }^{2)}($ 出 生中位推計）では、2036 年に老年人口は $33.3 \%$ で総人口の 3 分の 1 を占め、2053 年には総人口が 1 億人を割ると推計されている。この 背景に関わる都市計画施策として、国土交通省ではコンパクト十ネッ トワークの方針 ${ }^{3)}$ を示し、生活関連施設が立地する拠点と、拠点間 および拠点にアクセス寸る公共交通軸（以下、交通軸）の組合せか らなる都市構造の形成により、公的サービスの効率的提供を䄈らっ た都市計画を進めている。さらに、コンパクトなまちづくりを進め るうえで、客観的かつ定量的な分析、評価をもとにした目指す心゙き 都市構造の提示と、それらにより住民、民間事業者、行政等地域に おけるコンセンサスの醸成を求めている ${ }^{4)}$ 。
コンパクト十ネットワークの方針を実現する手段には、2014 年 8 月、2014年 11 月にそれぞれ創設された立地適正化計画、地域公共交 通網形成計画が提示されている。コンパクト+ネットワークの原点 は 2006 年の社会資本整備委員会 ${ }^{5)}$ によって示され ${ }^{6)}$ 、立地適正化計画、 地域公共交通網形成計画の創設以前から、拠点と公共交通機関によ るネットワーク化を都市計画マスタープランに位置付けていた市町 村も存在する。都市計画マスタープランの高度化版とされる立地適 正化計画は、拠点の範域である都市機能誘導区域に加え、都市機能 誘導区域内及び、交通軸上の駅やバス停から徒歩、自転車利用圈と なる範域に、人口密度の維持を図る居住誘導区域を設定することに より、利便性を担保した都市を実現しようとする制度であり、2019 年 3 月 31 日現在 468 の市町村で具体的な取組みが進められている ${ }^{7}$ 。

しかし、各市町村の拠点配置は、公的サービスの効率的提供を秝 らうことを目的にしているものの、アクセシビリティに関する客観 的かつ定量的な指針に基づいて検討されていない。特に、拠点形成 の実現手段として各市町村が設定している立地適正化計画の都市機 能誘導区域は、歴史的な市街地形成を考慮しつつ、(1)都市機能が一 定程度集積した地域、(2)公共交通へのアクセシビリティが高い地域 を設定基準の例としている ${ }^{8)}$ 。つまり、居住地から拠点へのアクセシ ビリティを確保するように需要分布に応じて拠点を配置するのでは なく、都市機能誘導区域での拠点形成と、交通軸周辺での居住誘導 によって需要分布を制御し、拠点へのアクセシビリティを確保する というアプローチである。したがって、現行のコンパクトシティ政
*1 宇都宮大学大学院工学研究科 博士課程 · 修士 (工学)

*2 宇都宮大学地域デザイン科学部 准教授・博士 (工学)

*3 自治医科大学地域医療学センター 助教・博士 (工学)

*4 宇都宮大学地域デザインセンター 特任助教・博士 (工学)
Doctor's Degree Course, Graduate School of Eng. Utsunomiya Univ., M.Eng. Assoc. Prof., Faculty of Regional Design, Utsunomiya Univ., Dr.Eng. Research Assoc., Center for Community Medicine, Jichi Medical Univ., Dr.Eng. Project Research Assoc., Center for Regional Design, Utsunomiya Univ., Dr.Eng. 
策による拠点配置は、居住地から拠点へのアクセシビリティが検討 の一基準とされていないため、公的サービスの提供に関わる効率化 へのインパクトが明らかではないことに課題が残る。以上より、居 住地から交通軸を基にした拠点へのアクセシビリティの観点から、 拠点配置計画と居住誘導計画を評価寸る手法の確立が求められる。

\section{2 理論的背景}

コンパクトシティの有効性はこれまでに数多く示されている。堀 $ら^{9)}$ は、 2 時点のパーソントリップ調査と人口分布構造から、コンパ クトシティが自動車利用を抑制させ、エネルギー消費量を減少させ ることを示した。森本 ${ }^{10)}$ は、コンパクトシティの評価指標として、 都市施設に関連する維持管理費等の都市財政と、都市内交通による $\mathrm{CO}_{2}$ 排出量からみた都市環境に着目し、特に都市構造の変化を大きく 受ける財政面において、シナリオ分析を通じてコンパクトシティが 効果的であることを示した。これらの実都市を対象とした研究によっ て、エネルギー消費量、都市財政、都市環境においてコンパクトシティ の有効性が示されているが、具体的な計画評価には至っていない。

コンパクトシティ実現への方策として、拠点の適正配置と人口集 約を衫らった居住誘導があげられるが、これらの計画評価として、 肥後ら ${ }^{11)}$ は、全国 39 都市の都市計画マスタープランを対象に、拠 点設定状況とその特徵を整理し、設定された拠点内の都市サービス 施設の集積率から、実態を伴わない拠点設定が計画されている傾向 を明らかにした。そのうえで、拠点配置に関する客観的な基準の必 要性を示唆している。これに関して、拠点配置に関する客観的な基 準の一つとして、総移動コストの最小化が挙げられる。鈴木 ${ }^{12)}$ 、腰 塚 ${ }^{13)}$ は、都市のコンパクトさについて、任意の 2 地点間の移動距離 の総和を最小にする都市構造であると定義し、最適な都市形態を示 している。また近藤ら ${ }^{14)}$ は、総移動コストの最小化に加え、拠点と 公共交通機関による都市構造を想定した理論モデルを構築した。拠 点を一つとした都市形態、階層的な拠点と公共交通機関による都市 形態が比較され、移動コストの観点から公共交通機関を活用し都市 を水平展開させることの有効性が示唆されている。さらに鈴木 ${ }^{15)}$ は、 minisum 型施設配置問題を基礎に、拠点配置問題と路線配置問題を組 み合わせ、予算制約のもとで拠点と路線配置を同時に決定する都市 構造問題を定式化した。一方で、拠点へのアクセシビリティの向上 を衫らった居住誘導に関連する既往研究として、坪井ら ${ }^{16)}$ は行政方 針から人口集約ルールを体系化し、将来推計人口を基に人口分布の 観点から、対象都市の将来的な都市構造を可視化した。そのうえで、 鉄道駅、総合病院の距離別人口カバー率から、人口集約により都市 施設への利便性が向上寸ることを明らかにした。

さらに、公共交通機関とアクセシビリティに関して、徒歩と公共 交通機関利用の組合せについて、以下の既往研究が挙げられる。鈴 木 ${ }^{17)}$ はバス停の配置方法について、バス利用者が歩行時間とバスの 乗車時間の和が最小となるように利用するものとして、バス停の最 適配置を示した。レら ${ }^{18)}$ は、鈴木と同様に、歩行時間と公共交通機 関利用時間の和が最小となるように移動する場合、年齢階級に応じ た移動コストを公共交通機関の種別ごとに定量化し、公共交通機関 の導入に関する指針を示した。

以上より、都市内の総移動コスト最小化による拠点の効率的配置 に関する研究や、居住誘導によるアクセシビリティ向上の効果を示 した研究はあるが、コンパクトシティの具体的な計画評価として、
両者を同時に扱った研究は少ない。そこで、拠点配置と居住誘導は、 転居、撤退に関する人口動態を予測することで、拠点へのアクセシ ビリティ向上への有効な方策としての可能性を検討できると考えた。

\section{3 研究の目的}

以上より、拠点と交通軸の組合せによる都市構造について、拠点 へのアクセシビリティに基づく拠点配置計画と居住誘導計画の評価 手法を示し、現行計画の交通軸上での拠点配置について、拠点の効 率的な配置計画を検討することを目的とする。本研究では、徒歩と 交通軸上の公共交通機関利用の組合せによる拠点への移動を想定す る。また、複数種類の公共交通機関を考慮することから、アクセシ ビリティ指標のひとつである移動距離について、居住地から交通手 段別に時間換算した移動時間を算出する。算出した拠点への平均移 動時間を指標として、拠点配置計画と居住誘導計画の誘導の効率性 を同時に評価する。

\section{2. 研究の方法}

はじめに、拠点への移動時間の計測方法を定義する。そのうえで、 拠点と交通軸によって将来的な都市構造を定める地方都市を実例と し、研究対象地域における現行の拠点配置について、居住誘導によ る影響を考慮した拠点への移動時間を算出する。分析には地理情報 システム（GIS）を用いる。さらに、現行計画の交通軸上を候補点と した拠点の最適配置を、総移動時間を最小化する minisum 基淮によっ て算出する。ただし本稿では、一部の拠点を固定した場合の、他の 地域拠点の配置手法を検討する。最適配置は、以下の 2 種による。 1）す心゙ての候補点を同等に扱った場合、2）立地適正化計画にお いて交通結節点として、拠点の設定基準に考慮されている鉄道駅を 地域拠点として固定した場合。最適配置の算出後、拠点への移動時間、 拠点の利用圈域から現行計画と最適配置を比較し、移動時間に基づ く拠点の効率的配置について考察する。

\section{1 研究対象地域の概要}

研究対象地域には、ネットワーク型コンパクトシティを将来的な 都市構造として掲げる栃木県宇都宮市を取り上げた ${ }^{19}$ ), 注1)（図 1、 表 1 )。栃木県の県庁所在地である宇都宮市は、首都圈北部に位置し、 昼夜間人口比率は $106.9 \%$ （2015 年国勢調查）と独立した衛星都市 としての特徴を有する。また、人口約 52 万人（2015 年国勢調查）を 有する地方中核都市であるが、今後の人口減少により、2035 年には 人口が 50 万人を下回ることが見込まれている ${ }^{20)}$ 。また土地利用の特 徵として、2007 年 3 月に上河内町、河内町との市町村合併を経て、 農業地域、工業地域を有した広汎な市域を持つ。同市は、2004 年以降、 生活に密着した行政サービスを提供する地区市民センターを中心と した地区行政を推進し、16 の地区行政単位を設定している ${ }^{21)}$, 22)。居 住誘導の分析では、この 16 地区を用いている。さらに「第 5 次宇都 宮市総合計画 ${ }^{23)} 」(2008$ 年 3 月 ) において、拠点化と拠点間の連携 を図る都市計画施策として、ネットワーク型コンパクトシティを将 来的な都市構造の理念として掲げ、 7 年後の「ネットワーク型コン パクトシティ形成ビジョン ${ }^{19)} 」(2015$ 年 2 月）には、具体的な拠点 配置が示された。当ビジョンの実現手段として、市街化区域では「宇 都宮市立地適正化計画 ${ }^{24)} 」(2017$ 年 3 月策定）による都市機能誘導区 域、市街化調整区域では「市街化調整区域の整備及び保全の方針 ${ }^{25)} 」$ （2018 年 3 月改定）による地域拠点を定め、中心市街地としての都市 


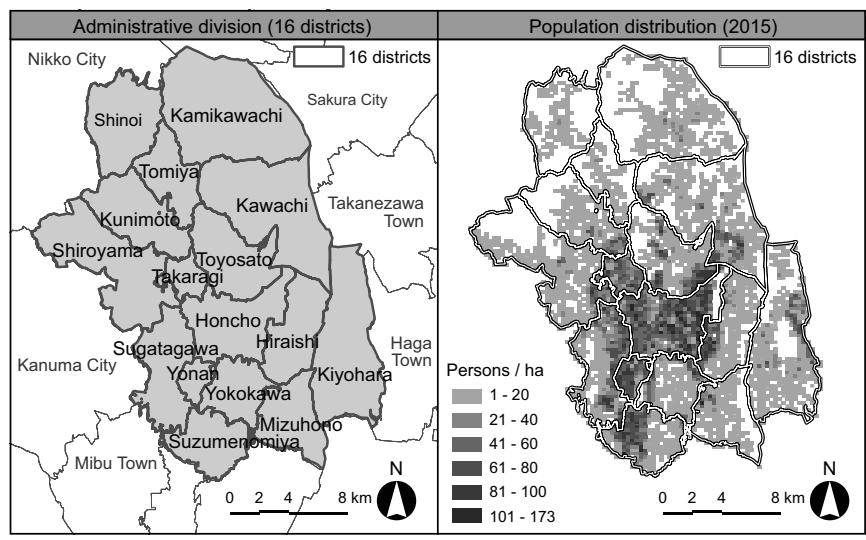

Fig.1 The study area

Table 1 Outline of the study area

\begin{tabular}{|l|r|r|r|r|r|r|r|r|}
\hline \multirow{2}{*}{ Districts name } & \multirow{2}{*}{ Persons } & \multirow{2}{*}{$\begin{array}{c}\text { Area } \\
\left(\mathrm{km}^{2}\right)\end{array}$} & $\begin{array}{c}\text { Population } \\
\text { density } \\
\text { (Persons / ha) }\end{array}$ & $\begin{array}{c}\text { Building } \\
\text { site }(\%)\end{array}$ & $\begin{array}{l}\text { Industrial } \\
\text { use }(\%)\end{array}$ & $\begin{array}{c}\text { Farmland } \\
(\%)\end{array}$ & $\begin{array}{c}\text { Nature } \\
\text { site }(\%)\end{array}$ & $\begin{array}{c}\text { Others } \\
(\%)\end{array}$ \\
\hline Honcho & 141,743 & 26.4 & 50.9 & 51.3 & 11.8 & 2.0 & 2.2 & 32.8 \\
\hline Takaragi & 29,966 & 6.9 & 43.4 & 50.5 & 0.7 & 12.8 & 5.2 & 30.8 \\
\hline Yonan & 28,830 & 5.1 & 56.1 & 54.3 & 2.7 & 3.9 & 1.4 & 37.7 \\
\hline Hiraishi & 31,306 & 21.1 & 14.8 & 22.2 & 2.7 & 44.3 & 4.1 & 26.7 \\
\hline Kiyohara & 27,697 & 42.1 & 6.6 & 12.4 & 7.3 & 37.6 & 18.4 & 24.3 \\
\hline Yokokawa & 22,619 & 15.7 & 14.4 & 24.2 & 3.4 & 44.6 & 5.2 & 22.6 \\
\hline Mizuhono & 9,832 & 19.5 & 5.0 & 11.6 & 2.3 & 44.3 & 8.9 & 32.8 \\
\hline Shiroyama & 22,859 & 39.4 & 5.8 & 11.0 & 1.3 & 28.9 & 46.8 & 12.1 \\
\hline Kunimoto & 14,173 & 24.3 & 5.8 & 11.6 & 2.3 & 44.3 & 8.9 & 32.8 \\
\hline Tomiya & 3,987 & 17.0 & 2.3 & 6.2 & 1.2 & 28.5 & 47.4 & 16.7 \\
\hline Toyosato & 40,642 & 24.7 & 16.5 & 20.9 & 1.2 & 31.1 & 21.9 & 25.0 \\
\hline Shinoi & 2,402 & 26.6 & 0.9 & 4.6 & 0.3 & 26.5 & 61.6 & 7.1 \\
\hline Sugatagawa & 56,051 & 23.8 & 23.5 & 30.9 & 1.4 & 33.1 & 10.2 & 24.3 \\
\hline Suzumenomiya & 41,961 & 18.0 & 23.4 & 29.2 & 1.7 & 42.3 & 3.7 & 23.1 \\
\hline Kamikawachi & 9,641 & 56.7 & 1.7 & 5.3 & 1.1 & 38.0 & 38.7 & 16.8 \\
\hline Kawachi & 34,884 & 47.6 & 7.3 & 12.1 & 2.1 & 47.1 & 18.4 & 20.2 \\
\hline All & 518,594 & 416.8 & 12.4 & 17.4 & 2.9 & 33.5 & 25.0 & 21.2 \\
\hline
\end{tabular}

拠点エリア（以下、都市拠点）と、他の 16 の拠点を指定している ${ }^{\text {注2) }}$ (図 2、表 2)。本稿では都市拠点以外の拠点をすべて地域拠点とし て扱う。なお、[5. ショッピングセンター前］、[11. 南宇都宮 $]$ の 2 拠点については計画上、地域拠点ではない都市拠点圈域とされてい るが、本研究では都市拠点と分離しているため、地域拠点として分 析する。交通軸には、鉄道、LRT (2022 年開業予定)、幹線バス路線 が同計画内で交通ネットワーク注3) として指定されており、本研究で はこれらの都市拠点から放射状に整備されている交通軸を踏襲したa

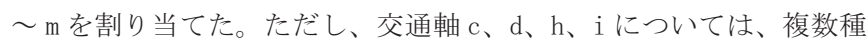
類の公共交通機関によって、すべてもしくは一部共通の地域拠点を つないでいるため 1 本の交通軸とみなす。将来的な居住誘導につい ては、市街化区域内の拠点域、鉄道を除く交通軸から歩行により移 動可能な範囲には、将来的に人口密度を維持・確保する居住誘導区 域が設定されている ${ }^{24)}$ 。また、市街化調整区域の地域拠点域におい

\section{ても居住誘導が図られる ${ }^{25)}$ 。}

\section{2 拠点への移動時間の計測方法}

本研究では、居住者は居住地から移動時間が最短となる拠点を最 寄り拠点として、移動すると想定する。最寄り拠点への到達は、市 が指定している拠点域内の代表的な駅・停留所への到達とし、路線 ごとに定めた（図 3 ）。ただし、都市拠点に定められたエリアについ ては広汎な拠点域をもつことから、利用者から最も近い都市拠点内 の駅・停留所とした。また、徒歩による都市拠点への到達は、拠点 域と後述する道路ネットワークデータが交差する点での到達を想定

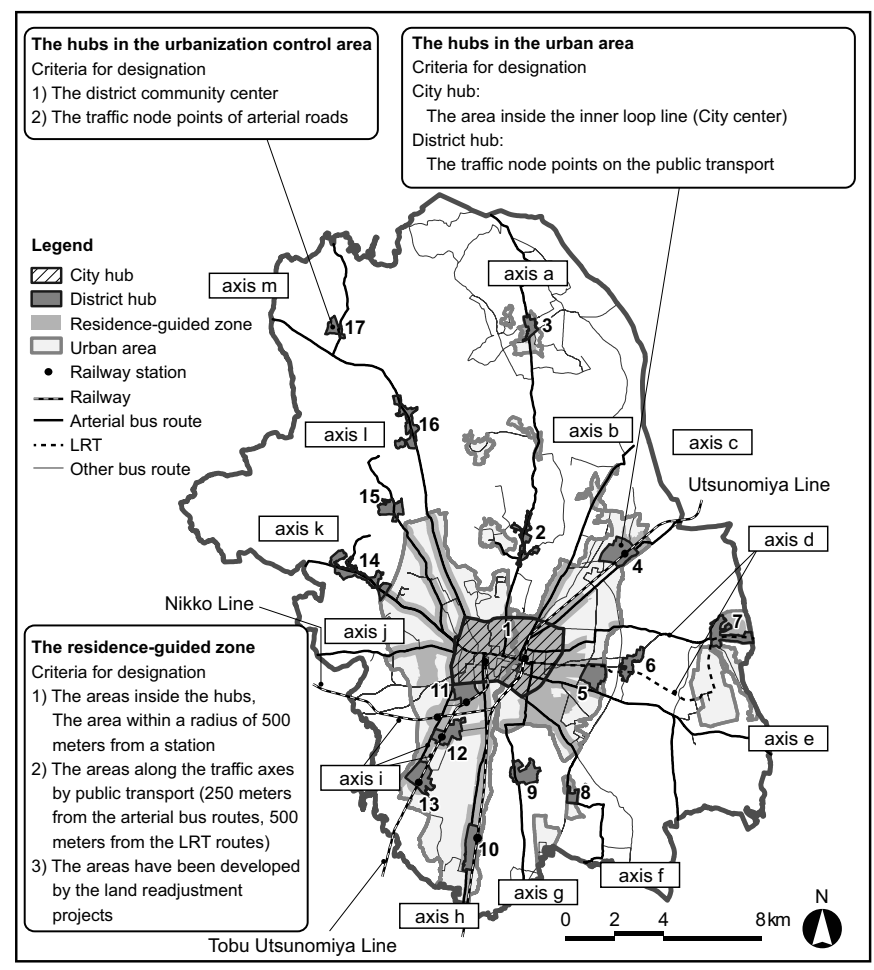

Fig.2 Future urban structure of the study area

Table 2 Outline of the hubs

\begin{tabular}{|l|l|l|l|}
\hline \multicolumn{2}{|c|}{ No. I Abbreviated name } & \multicolumn{1}{|c|}{ Official name } & \multicolumn{1}{c|}{$\begin{array}{c}\text { Traffic axis } \\
\text { between hubs }\end{array}$} \\
\hline 1 & City center & City center area & All axis \\
\hline 2 & Toyosato & Area around Toyosato Chuo Elementary School & a (Bus) \\
\hline 3 & Kamikawachi & Area around Kamikawachi Civic Center & a (Bus) \\
\hline 4 & Okamoto & Area around Okamoto Station & c (Railway, Bus) \\
\hline 5 & Shopping Center-mae & Area around the LRT stop (Shopping Center-mae) & d (LRT) \\
\hline 6 & Hiraishi & Area around Hiraishi Civic Center & d (LRT) \\
\hline 7 & Technopolis & Technopolis-center area & d (LRT, Bus) \\
\hline 8 & Mizuhono & Area around Mizuhono apartment complex & f (Bus) \\
\hline 9 & Yokokawa & Area around Yokokawa Civic Center & g (Bus) \\
\hline 10 & Suzumenomiya & Area around Suzumenomiya station & h (Railway, Bus) \\
\hline 11 & Minami-utsunomiya & Area around Minami-utsunomiya station & i (Railway) \\
\hline 12 & Esojima & Area around Esojima station & i (Railway, Bus) \\
\hline 13 & Nishikawata & Area around Nishikawata station & i (Railway, Bus) \\
\hline 14 & Shiroyama & Area around Shiroyama Civic Center & j (Bus) \\
\hline 15 & Kunimoto & Area around Kunimoto Civic Center & k (Bus) \\
\hline 16 & Tomiya & Area around Tomiya Civic Center & I (Bus) \\
\hline 17 & Shinoi & Area around Shinoi Civic Center & m (Bus) \\
\hline
\end{tabular}

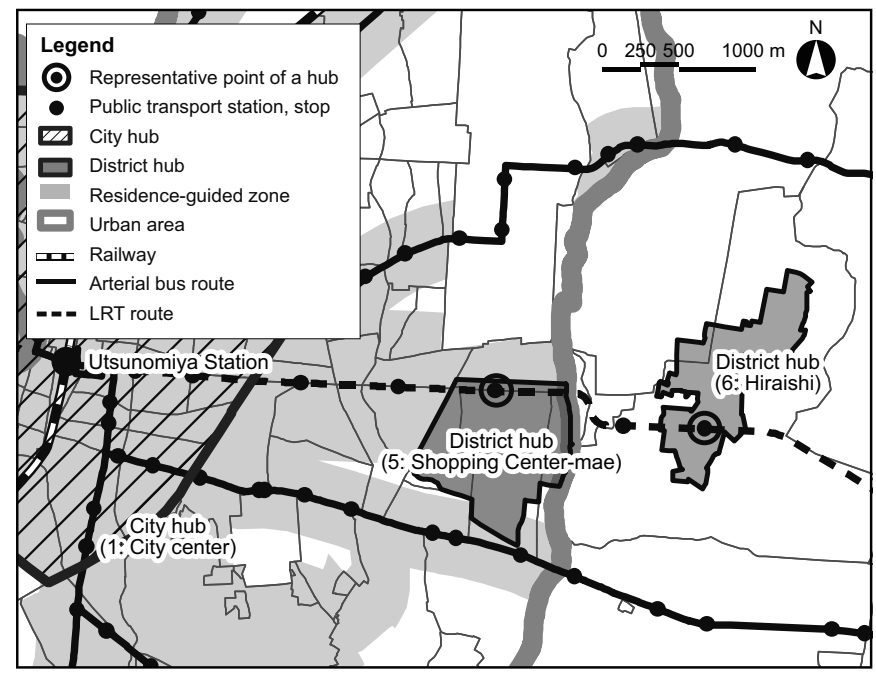

Fig.3 Example of representative points 
した。移動時間は、歩行時間 $T_{w}$ と公共交通機関利用時間 $T_{p}$ の合計 移動時間 $T$ とし、これが最短となるように、拠点を選択する（以下、 最寄り拠点）ものとした（図 4)。なお、利用を想定する公共交通機 関は、図 2 に示寸交通軸のみとし、利用者は所要時間の最も短い公 共交通機関を利用するものとする衤4)。ただし、待ち時間は考慮しない。 移動時間の算出は、距離計測した值を時間換算することにより行っ た。距離計測には地理情報システム ArcGIS（ESRI ジャパン株式会社） の Network Analystツールを使用し、100mメッシュの重心点を居住 地とし、最寄り拠点までの距離を計測した。時間換算に用いる移動 速度（表 3 ）について、鉄道は駅区間ごとの発着時間を閲覧可能で ある時刻表（平日） ${ }^{26)}$ より、路線ごとに移動速度を算出し、東武宇 都宮線 752m/min、宇都宮線 1092m/min、日光線 $917 \mathrm{~m} / \mathrm{min}$ とした。他 の LRT、幹線バスは文献 ${ }^{27}$, 28) を参照し、それぞれ $30 \mathrm{~km} / \mathrm{h}$ より $500 \mathrm{~m} /$ $\mathrm{min} 、 20 \mathrm{~km} / \mathrm{h}$ より $333 \mathrm{~m} / \mathrm{min}$ とした。歩行速度は、一般的な歩行速度 として標準歩行速度 $4 \mathrm{~km} / \mathrm{h}$ より、 $67 \mathrm{~m} / \mathrm{m}$ in とした。道路距離の計測 に用いた道路ネットワークデータは、基盤地図情報の道路縁（更新 日 2018 年 1 月 1 日〜 2018 年 7 月 1 日時点）を基に奥秋 ${ }^{29)}$ の方法を 用いた注5)。また、公共交通機関の路線、駅・停留所の地理情報につ いて、LRT は「芳賀・宇都宮東部地域公共交通網形成計画 ${ }^{30)} 」(2015$ 年 11 月策定）を参照して作成し、鉄道、幹線バス路線は国土数值情 報ダウンロードサービスより入手し、2018 年時点の路線図 ${ }^{31)}$ を参照 して一部データを加工した。さらに、本研究で着目する公共交通機 関利用の移動特性を把握するための比較分析として、自家用車によ る直接の拠点利用畤の移動時間を算出する。自家用車の速度は、平 成 27 (2015) 年度全国道路・街路交通情勢調查、栃木県の一般道路 における昼間 12 時間平均旅行速度 $33.8 \mathrm{~km} / \mathrm{h}$ より $563 \mathrm{~m} / \mathrm{min}$ とした。

\section{3 分析の方法}

\section{1 ) 現行計画に関する拠点配置の評価手法}

$100 \mathrm{~m}$ メッシュ単位で推定した居住者分布をもとに、現行計画の拠 点配置について、最寄り拠点への移動時間を算出した。また、立地 適正化計画の居住誘導による移動時間の縮減効果を把握するため、 居住者分布は現状の人口と将来人口について推定した。

\section{(1) 居住者分布の推定}

後述する拠点の利用圈域内人口の基準とする現状の人口に関する 居住者分布は、2015 年国勢調查から 100m メッシュ人口を作成し使用 した。作成には、建物ポイントデータ(株式会社ゼンリン、2017 年取得) の「家屋の延床面積」に面積按分し、100mメッシュで再集計するこ とによる。また将来人口については、居住誘導を実施しない設定 1 : 趨勢と、2020 年から居住誘導を開始する設定 2 : 居住誘導実施の 2 つの条件で 5 年ごとに推定した。設定 1 は、小地域別の将来推計人 口 ${ }^{32)}$ を、同様に建物ポイントデータの「家屋の延床面積」を用いて 面積按分し、100m メッシュ単位に再集計することで推定した。設定 2 は、都市拠点と地域拠点の拠点域と、居住誘導区域を合算した地 域（以下、誘導エリア）の外において、2020 年より新たな転入がで

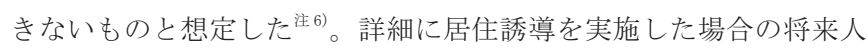
口を予測するためには新たな将来人口推計モデルの構築が必要にな るため、本稿では簡易的な手法により推定した。具体的には、誘導 エリア外において想定される転出入人口のうち、転入超過人口を誘 導対象人口として扱い、これらは各 16 地区内の誘導エリア内におい て転入するものとした注7) (図 5 )。誘導対象人口は、小地域別に算出

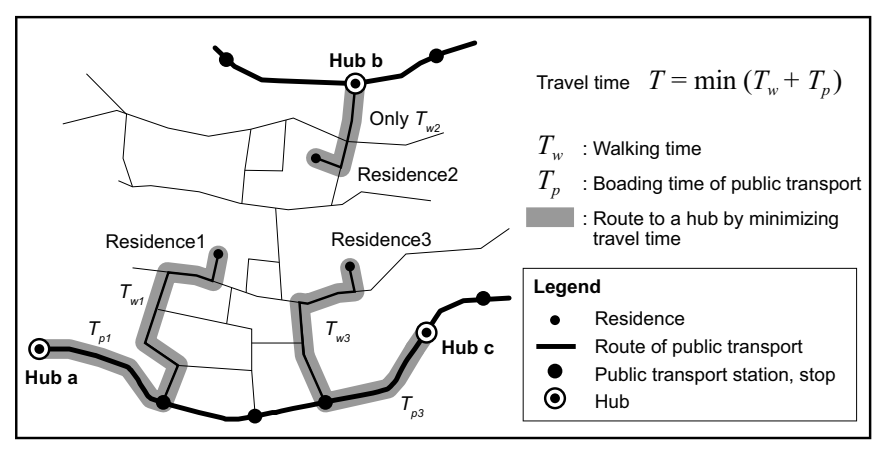

Fig.4 Method of accessing a hub

Table 3 Moving speed of public transportation

\begin{tabular}{|c|c|c|}
\hline \multirow{3}{*}{ Railway $^{26)}$} & Public transport & Moving speed $(\mathrm{m} / \mathrm{min})$ \\
\cline { 2 - 3 } & Tobu Utsunomiya Line & 752 \\
\cline { 2 - 3 } & Utsunomiya Line & 1092 \\
\hline \multicolumn{2}{|c|}{ Nikko Line } & 917 \\
\hline \multicolumn{2}{|c|}{ LRT route $^{27)}$} & 500 \\
\hline Arterial bus route $^{28)}$ & 333 \\
\hline
\end{tabular}

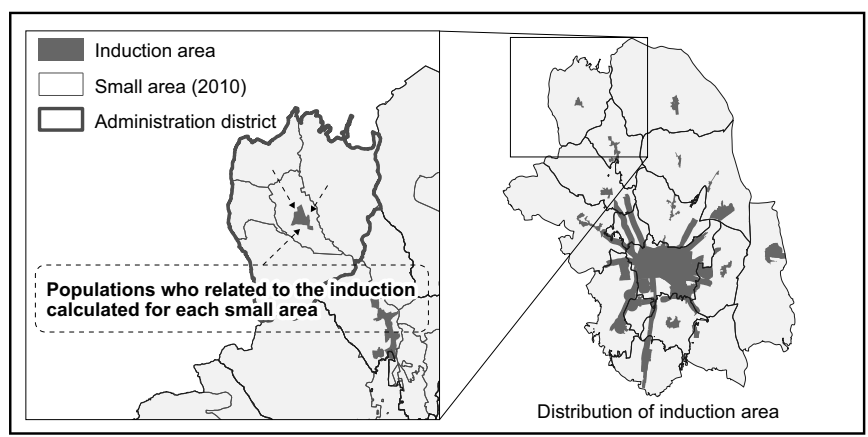

Fig.5 Estimating population of setting2

し、建物ポイントデータに面積按分することで、誘導エリア内外の 人口を判断する。算出には、先述した小地域別の将来推計人口 ${ }^{32)}$ と、 将来の生存率 ${ }^{33}$ を用いて予測する 5 年後の生存人口を用いる。算出 式を以下のように定義する。ここで、 $i$ は市区町村 $I$ に属する小地域 として、 $t$ 年の年齢別の人口を以下のように定義すると、

$g$ :

$P_{i}^{g}(x, t): \quad t$ 年 10 月 1 日現在における小地域 $i$ の年齢階級 $x$ $\sim x+4$ 歳の性別 $g$ 人口

$S P_{i}^{g}(x+5, t+5): t$ 年 10 月 1 日現在における小地域 $i$ の年齢階級 $x$ $\sim x+4$ 歳の性別 $g$ 人口が、 $t+5$ 年 10 月 1 日まで に転出入する当該年齢階級の性別 $g$ 人口

$N P_{i}^{g}(x+5, t+5): t$ 年 10 月 1 日現在における小地域 $i$ の年齢階級 $x$ $\sim x+4$ 歳の性別 $g$ 人口が、 $t+5$ 年 10 月 1 日まで に生存する当該年齢階級の性別 $g$ 人口

小地域 $i$ の $t \sim t+5$ 年における転出入人口（誘導対象人口）は、

$S P_{i}^{g}(x+5, t+5)=P_{i}^{g}(x+5, t+5)-N P_{i}^{g}(x+5, t+5)$

となり、 5 歳階級ごとの将来の生存率を、

$R_{I}^{g}(x, t): \quad t$ 年 10 月 1 日現在における $I$ 市の年齢階級 $x \sim$ $x+4$ 歳の性別 $g$ 人口が $t+5$ 年 10 月 1 日に $x+5 \sim$ $x+9$ 歳まで生存する確率

$R_{I}^{g}(85 \mathrm{over}, t): t$ 年 10 月 1 日現在における $I$ 市の年齢階級 85 歳の 性別 $g$ 人口が $t+5$ 年 10 月 1 日に 90 歳以上まで生 存する確率

とすると、生存人口 $N P_{i}^{g}(x+5, t+5)$ は、 $x<80$ のとき、 


$$
N P_{i}^{g}(x+5, t+5)=P_{i}^{g}(x, t) \cdot R_{I}^{g}(x, t)
$$

により算出する。ただし、 $x \geqq 80$ のとき、

$$
N P_{i}^{g}(x+5, t+5)=P_{i}^{g}(80, t) \cdot R_{I}^{g}(80, t)+P_{i}^{g}(x+5, t) \cdot R_{I}^{g}(85 \text { over }, t)
$$

とする。なお、この算出方法は、国勢調查および全国小地域別将来 人口推計システムで、8 8 歳以上の人口がまとまって集計されている ことによる。

\section{(2) 最寄り拠点への移動時間}

市域に重複する各 $100 \mathrm{~m}$ メッシュから現行計画の最寄り拠点への移 動時間を算出した。さらに、算出した結果をもとに、ネットワーク ボロノイを示す拠点の利用圈域図を作成した。算出結果と拠点の利 用圈域から、拠点の利用圈域ごとの平均移動時間、利用圈域内人口 などの特徴を把握する。 3 章では、現行計画の特徴を把握するために、 現行の拠点配置に関する移動時間を算出した。算出は、現状の人口 をもとに、公共交通機関利用に加え、先述した比較分析として直接 拠点を利用寸る自家用車利用の 2 パタンで行った。さらに、公共交 通機関利用については、立地適正化計画における居住誘導による移 動時間の縮減効果を把握するため、現状の人口と将来人口を基にし た分析を行った。

\section{2 ） p-median 問題による地域拠点の最適配置}

移動時間に基づく拠点配置の検討において、施設配置理論の適用 が有効な手法のひとつである。特に効率性を重視した施設配置計画 の評価指標に、総移動距離の最小化（minisum 基準）が挙げられ、総 移動距離の最小化を目的関数とした施設配置問題には、 $p$-median 問 題が定式化されている ${ }^{34)} 。 p$-median 問題は、需要点と施設候補点 が離散的に与えられたもとで、需要点から施設までの最短移動距離 の総和を最小化するように $p$ 個の施設を配置する離散型モデルであ る。 $p$-median 問題は、人口分布等による需要分布と道路網の実デー 夕を用いた実証的研究において、記述性の高さが示されている ${ }^{35)}$ 。 本稿では、総移動距離の最小化を総移動時間の最小化に読み替え、 $p$-median 問題により、都市拠点を除く 16 の地域拠点について、公共 交通利用を想定した際の最適配置を算出した。最寄り拠点への移動 距離が最小となるように、 $p$ 個の地域拠点を求解する問題は、以下の 式で表す。

$\min Z$

$$
\begin{array}{lll}
\text { s.t. } & Z=\Sigma_{i} d_{i} \sum_{j} c_{i j} x_{i j} & \\
& \sum_{j} x_{i j}=1 & \forall i \\
& x_{i j} \leq y_{j} & \forall i, j \\
& \Sigma_{j} y_{j}=p &
\end{array}
$$

ただし、

$$
\begin{array}{ll}
Z: & \text { 全需要の最寄り拠点への総移動時間 } \\
x_{i j} \in\{0,1\}: & \text { 需要点 } i \text { から拠点候補点 } j \text { への移動の有無を示 } \\
& \text { 寸 } 0-1 \text { 変数 } \\
y_{j} \in\{0,1\}: & \text { 拠点候補点 } j \text { での配置の有無を示す } 0-1 \text { 変数 } \\
d_{i}: & \text { 需要点 } i \text { の需要 } \\
c_{i j}: & \text { 需要点 } i \text { から拠点候補点 } j へ の \text { 最短移動時間 }
\end{array}
$$

である。また、最適配置は、候補点すべてを同等に扱った場合（条 件 1) と、鉄道駅を地域拠点として固定した場合（条件 2）の 2 条 件で算出する。現行計画において鉄道駅は、交通結節点として、市 街化区域内の地域拠点の設定基準のひとつであり、都市拠点域内の

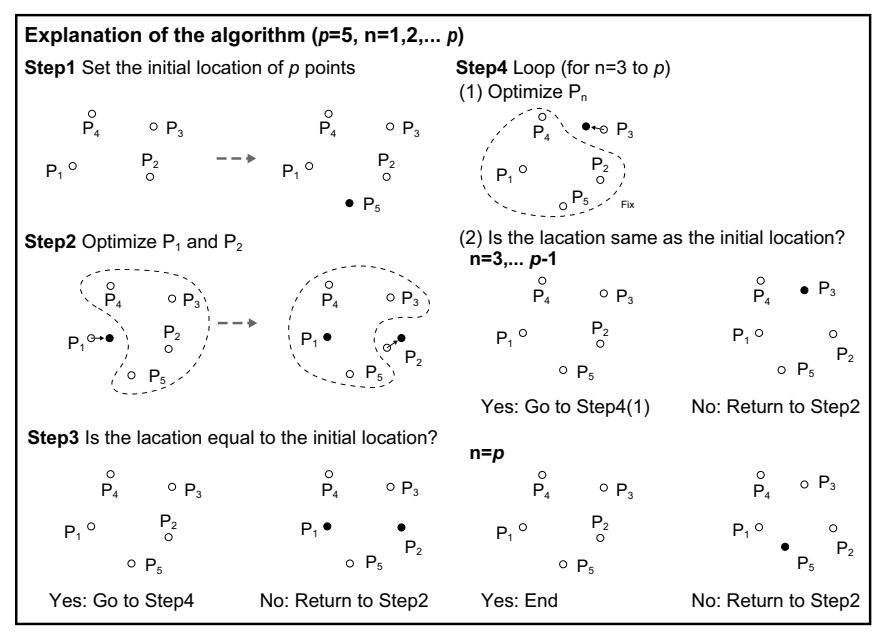

Fig.6 Outline of the algorithm

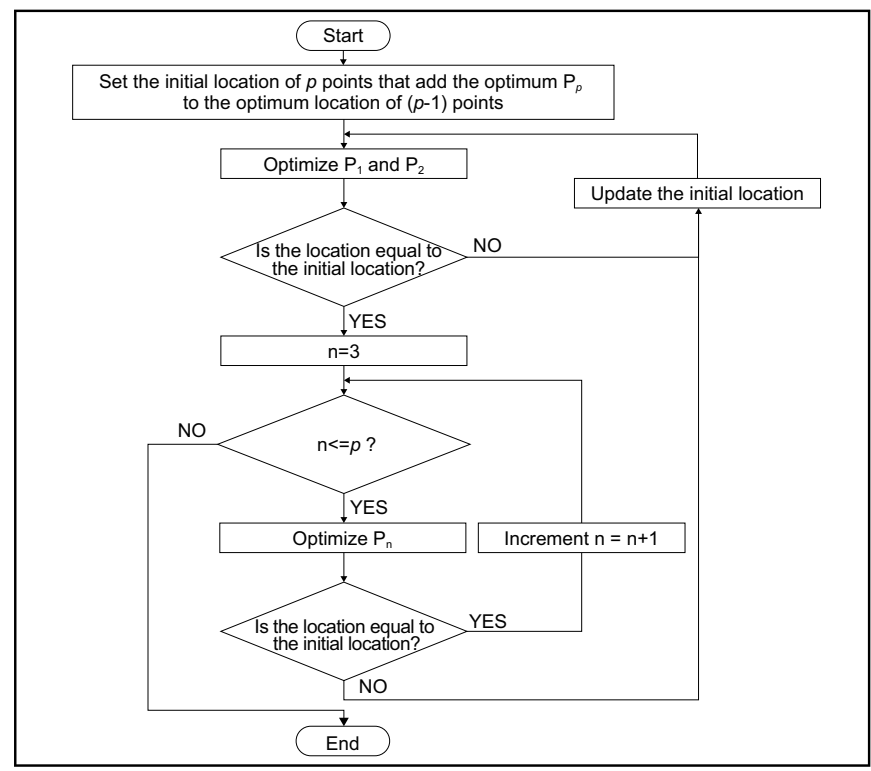

Fig.7 Algorithm flowchart

2 駅を除く 6 の鉄道駅のうち、 5 駅が地域拠点として指定されてい る ${ }^{\text {i注 }}$ 。拠点の候補点は、現行計画の交通軸（鉄道、幹線バス路線、 LRT）上における、都市拠点を除いた各駅、停留所を基本とする。た だし、先述した現行計画において共通の拠点間を複数種類の公共交 通機関がつなぐように、複数種類の公共交通機関が近接している場 合の処理を行う。具体的には、基幹公共交通である鉄道、LRT の駅・ 停留所から道路距離 600m（TOD：公共交通指向型開発を参照）に幹線 バスの停留所が存する場合、各点から最も近い幹線バスの停留所は 鉄道、LRT の駅・停留所と同じ候補点として、候補点の集約を行った。 以上の処理の結果、拠点の候補点は 305 点である。需要と需要点は、 2015 年国勢調查の $500 \mathrm{~m}$ メッシュ人口とのその重心点 (市内 1,608 点) を用いた。なお、最適配置の算出には、逐次最適化によるアルゴリ ズムを用い、近似解を得た (図6、図 7 )。

\section{3. 現行計画に関する拠点配置の評価の結果 \\ 3. 1 居住者分布の推定結果}

2015 年国勢調查を現況とし、推計可能であった 2040 年までの居住 者分布を推定した。なお、「宇都宮市立地適正化計画」では計画時点 
(2017 年) の 20 年後である 2037 年を目標年次として計画されてい る。誘導エリア内外の集計による推計結果を表 4 、表 5 に示す。表 4 、 5 より、総人口は 2015 年の約 52 万人から 2040 年には約 42 万人ま で減少が見込まれている。さらに表 6 に、設定 2 における誘導エリ ア内外の転入超過人口の累積值を示寸注6)。誘導エリア外の転入超過 人口が誘導対象人口であるので、2040 年までに誘導対象人口は、総 人口約 42 万人のうち約 6,000 人となる。

\section{2 最寄り拠点への移動時間の結果}

現行の拠点配置に対する移動時間分布、拠点ごとの特徵を、自家 用車利用（図 8、表 7) と、公共交通機関利用（図 9、表 8) のそ れぞれを示す。市内全域の平均移動時間について、公共交通機関利 用では 13.4 分であるのに対して、自家用車利用は 2.53 分と短いこ とがわかる。ただし、杤木県全域の自動車速度を採用しているため、 同市の評価としては過大である可能性に留意が必要である。移動時 間分布を比較すると、自家用車利用では、各拠点を中心として同心 円状に移動時間が増大していくのに対し、公共交通機関利用では、 交通軸から離れるに従って、移動時間が増大し、交通軸間、市辺縁 部に移動時間の大きい地域がみられる。また、地域拠点が配置され ていない幹線バス路線による交通軸（交通軸 b、e、j）の沿線では、 都市拠点が最寄り拠点となる地域が分布している。

公共交通機関利用時について、都市拠点を除く拠点ごとに想定さ れる利用圈域内人口をみると（2015 年）、最も多い［10．雀宮］と最 も少ない [17. 篠井］では 20 倍以上の差異がみられ、移動時間につ いて拠点間の不均衡が指摘できる。また、広汎な利用圈域をもつ $[3$. 上 河内］の平均移動時間は 31.6 分と突出していることから、最寄り拠 点への移動時間について、拠点ごとに大きな差がみられた。さらに 設定 1 の 2015 年と設定 2 の 2040 年の公共交通機関利用時の移動時 間を比較すると (表 9 )、市内の平均移動時間は 13.4 分から 13.3 分 と $1.32 \%$ の減少であり、現行計画の居住誘導による都市内の移動時 間の縮減は限定的と考えられる。拠点ごとの平均移動時間では、平 均移動時間が小さくなる拠点がみられる一方で、[9. 横川]をはじめ として [3. 上河内 ]、[5. ショッピングセンター前]、[6. 平石 $] 、[7$. テ クノポリス]、[16. 富屋］の 6 拠点では平均移動時間が大きくなる など、居住誘導と効率的に連携していない拠点の配置が示唆された。 本研究では、16 地区ごとの居住誘導を想定したが、交通軸と拠点配 置を考慮した居住誘導先の設定等、複合的な計画が求められる。本 研究では、交通軸沿線での居住誘導による移動時間の大きな縮減が 見込まれない点から、4 章の最適配置では現状の需要分布（2015 年 国勢調查の 500mメッシュ人口）を用いた。

\section{4. 移動時間を最小化する地域拠点の最適配置の算出}

\section{4. $1 p$-median 問題の導入と最適配置}

現行計画と同数の 16 の地域拠点について、最適配置を算出後、3 章と同様の手法により、公共交通機関利用時の移動時間分布、拠点 の利用圈域図を作成した。鉄道駅を地域拠点として固定しない条件 1 では、最適配置によって鉄道駅に配置される拠点を把握し、鉄道 駅を地域拠点として固定する条件 2 では、鉄道駅以外の配置される 拠点位置について現行計画、条件 1 と比較し考察する。

\section{1) 条件 1：鉄道駅を地域拠点として固定しない場合}

はじめに、鉄道駅を固定しない場合の最適配置を算出した（図 $10 、$
Table 4 Population estimation (Setting1)

\begin{tabular}{|c|c|c|c|}
\hline Year & $\begin{array}{c}\text { Inside the induction area } \\
\text { (Persons) }\end{array}$ & $\begin{array}{c}\text { Outside the induction area } \\
\text { (Persons) }\end{array}$ & $\begin{array}{c}\text { Sum } \\
\text { (Persons) }\end{array}$ \\
\hline 2015 & 244,403 & 274,403 & 518,594 \\
\hline 2020 & 234,021 & 265,555 & 499,576 \\
\hline 2025 & 226,992 & 257,566 & 484,558 \\
\hline 2030 & 218,543 & 247,554 & 466,097 \\
\hline 2035 & 209,320 & 235,920 & 445,240 \\
\hline 2040 & 199,656 & 223,547 & 423,203 \\
\hline
\end{tabular}

Table 5 Population estimation (Setting2)

\begin{tabular}{|c|c|c|c|}
\hline Year & $\begin{array}{c}\text { Inside the induction area } \\
\text { (Persons) }\end{array}$ & $\begin{array}{c}\text { Outside the induction area } \\
\text { (Persons) }\end{array}$ & $\begin{array}{c}\text { Sum } \\
\text { (Persons) }\end{array}$ \\
\hline 2015 & 244,403 & 274,403 & 518,594 \\
\hline 2020 & 234,021 & 265,555 & 499,576 \\
\hline 2025 & 228,707 & 255,851 & 484,558 \\
\hline 2030 & 221,856 & 244,241 & 466,097 \\
\hline 2035 & 214,156 & 231,084 & 445,240 \\
\hline 2040 & 205,840 & 217,363 & 423,203 \\
\hline
\end{tabular}

Table 6 The cumulative over population of moving-in

\begin{tabular}{|c|c|c|c|}
\hline Section & $\begin{array}{c}\text { Inside the induction area } \\
\text { (Persons) }\end{array}$ & $\begin{array}{c}\text { Outside the induction area } \\
\text { (Persons) }\end{array}$ & $\begin{array}{c}\text { Sum } \\
\text { (Persons) }\end{array}$ \\
\hline $2020-2025$ & 1,816 & 1,715 & 3,531 \\
\hline $2025-2030$ & 3,468 & 3,313 & 6,781 \\
\hline $2035-2040$ & 5,138 & 4,835 & 9,973 \\
\hline $2040-2045$ & 6,678 & 6,184 & 12,862 \\
\hline
\end{tabular}

表 10)。現行計画の結果（図 9）と最適配置を比較すると、平均移動 時間は 13.4 分から 12.4 分へ $7.6 \%$ 減少し、居住誘導の実施よりも移 動時間が縮減された。また、現行計画では 20 倍の差がみられた地域 拠点の利用圈域別人口は、最も多い $[\mathrm{I}]$ と最も少ない $[\mathrm{G}]$ の差が 約 10 倍となり、移動時間の観点から拠点間の不均衡が是正された。

また、交通軸ごとの地域拠点数について最適配置と現行計画を比

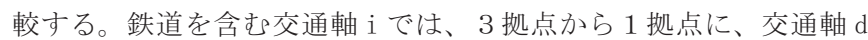
における LRT 上の地域拠点は 3 拠点から 1 拠点に、拠点数を減らした。 現行計画と比較すると、鉄道や LRT 等の基幹公共交通上は地域拠点 を減らす結果となった。理由として、基幹公共交通は速達性が高い ため、都市拠点をはじめとして周辺拠点へのアクセスが安易である ことが考えられる。加えて、幹線バス路線上に多くの地域拠点が最 適配置されたのは、幹線バスは停留所間隔が短いため、利便性が高 いことが反映された結果と考えられる。

\section{2 ）条件 2 : 鉄道駅を地域拠点として固定した場合}

都市拠点域内の 2 駅を除 $<6 つ$ つ鉄道駅 $[\mathrm{C}] 、[\mathrm{H}] 、\left[\mathrm{I}_{1}\right] \sim\left[\mathrm{I}_{4}\right]$ を 地域拠点として固定した場合の最適配置を算出した（図 11、表 11）。 ただし、 $\left.\mathrm{I}_{2}\right]$ については現行計画において地域拠点に指定されてい ないが、今後拠点の指定が検討されている ${ }^{24)}$ 。平均移動時間について、 鉄道駅を固定しない場合の 12.4 分と比較すると、12.7 分と長い。交 通軸ごとの地域拠点数は、鉄道駅を固定しない場合の最適配置（図 9) と比較すると、交通軸ｉ は、鉄道駅の固定しない場合の 1 拠点から、 鉄道駅の固定によって 4 拠点となる。交通軸 e、h については、2 拠 点から 1 拠点に拠点数を減らした。また、条件 1 ではすべての交通 軸に拠点が配置されたが、条件 2 では交通軸 $\mathrm{g}$ においては拠点数が 0 となった。以上より、鉄道駅を交通結節点として安易に拠点化す ると、移動時間の観点では、鉄道駅を固定しない場合よりも非効率 な拠点配置となることに注意が必要である。これら 2 点の最適配置 の結果について、移動時間の観点から、鉄道駅を固定しない（条件 1) の最適配置が有効な結果であるといえる。また、最適配置（表 $10 、$ 表 11) では、現行計画 (表 8) に比べて移動時間の最大值が大きくなっ た。これは、総移動時間最小化により、需要（人口）が小さい地域 


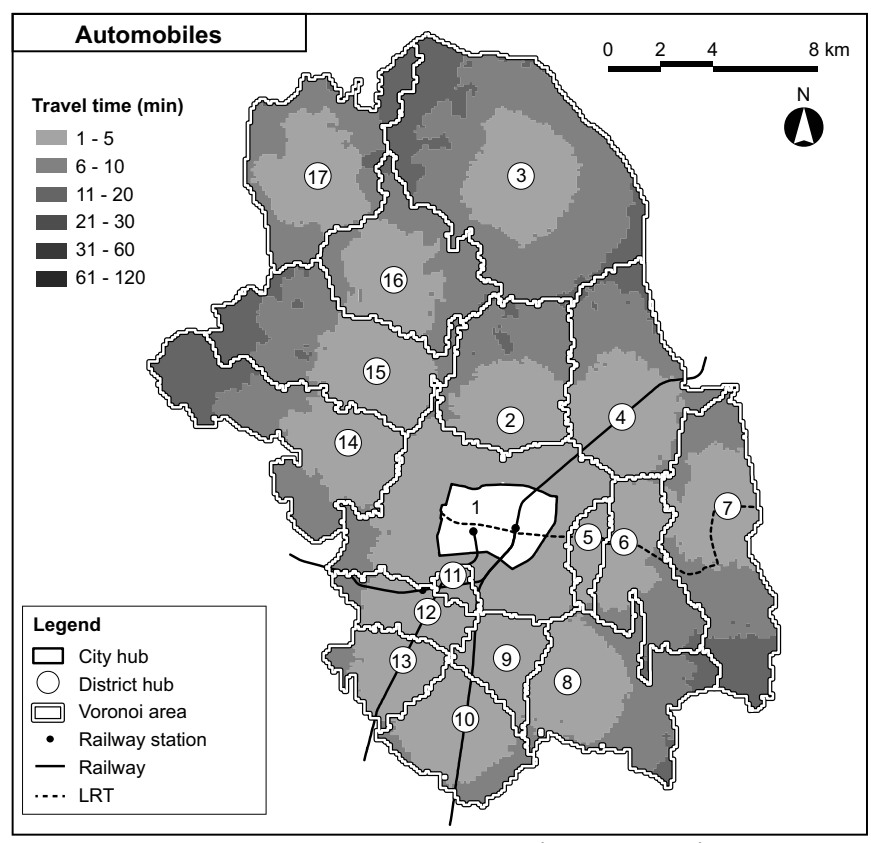

Fig.8 Travel time distribution (Automobiles)

Table 7 Travel time of each hub (Automobiles, Setting1: 2015)

\begin{tabular}{|c|l|c|c|c|}
\hline \multicolumn{2}{|c|}{ No. / Abbreviated name } & $\begin{array}{c}\text { User population } \\
\text { (Persons) }\end{array}$ & $\begin{array}{c}\text { Average travel time } \\
\text { (min) }\end{array}$ & $\begin{array}{c}\text { Maximum travel time } \\
\text { (min) }\end{array}$ \\
\hline 1 & City center & 218,851 & 1.54 & 8.0 \\
\hline 2 & Toyosato & 19,141 & 4.25 & 10.4 \\
\hline 3 & Kamikawachi & 12,571 & 5.03 & 14.8 \\
\hline 4 & Okamoto & 34,105 & 3.51 & 12.0 \\
\hline 5 & Shopping Center-mae & 16,348 & 2.20 & 5.9 \\
\hline 6 & Hiraishi & 9,755 & 4.88 & 10.9 \\
\hline 7 & Technopolis & 23,034 & 4.12 & 13.9 \\
\hline 8 & Mizuhono & 17,076 & 3.53 & 11.8 \\
\hline 9 & Yokokawa & 10,007 & 2.95 & 5.2 \\
\hline 10 & Suzumenomiya & 43,267 & 2.59 & 7.0 \\
\hline 11 & Minami-utsunomiya & 8,452 & 1.59 & 4.0 \\
\hline 12 & Esojima & 31,296 & 1.99 & 7.7 \\
\hline 13 & Nishikawata & 21,556 & 2.10 & 7.0 \\
\hline 14 & Shiroyama & 22,984 & 3.85 & 14.8 \\
\hline 15 & Kunimoto & 19,501 & 3.51 & 9.3 \\
\hline 16 & Tomiya & 8,140 & 5.29 & 10.3 \\
\hline 17 & Shinoi & 2,508 & 3.02 & 13.0 \\
\hline & \multicolumn{1}{|c|}{ All } & 518,594 & 2.53 & 14.8 \\
\hline
\end{tabular}

Low value in a column

High value in a column

で拠点への移動時間が増大したためと考えられるが、効率性のみを 重視した minisum 基準を用いた場合には避けられない結果である。

\section{2 地域拠点に関する現行計画と最適配置の比較}

地域拠点について現行計画の配置と、最適配置を比較し、最適配 置の特徵を整理した（図 12）。まず、最適配置された 16 の地域拠点 のうち 6 拠点（全体の $37.5 \%$ ) が、現行計画で指定された拠点の領 域内に配置された。したがって、地域拠点への移動手段に公共交通 機関利用を想定した場合、現行計画の地域拠点について、16 拠点の うち 6 拠点は、拠点位置の妥当性が高いといえる。次に、現行計画

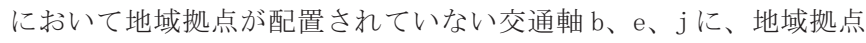
が最適配置された。逆に、現行計画で拠点が指定されている地域の うち、都市拠点に隣接する地域や、市の辺縁部では、地域拠点が配 置されない地域がみられた。その他、現行計画の拠点利用圈域内に おいて位置が変化する地域拠点、現行計画の拠点間に新たに最適配 置される地域拠点など、人口分布に依存した最適化による拠点位置 の変化がみられた。

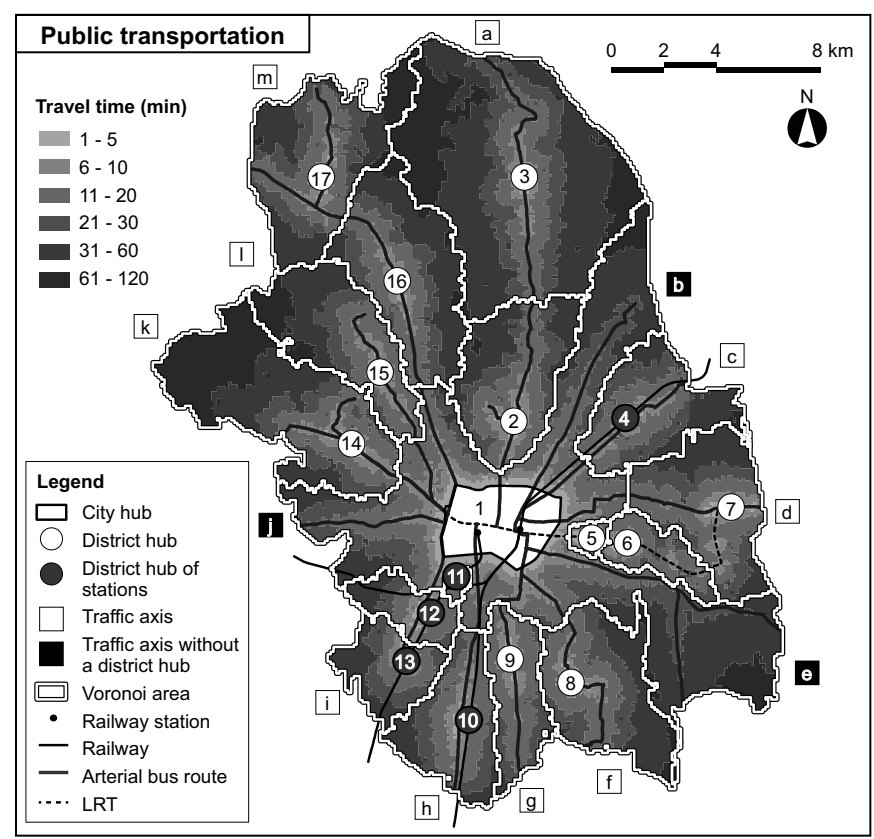

Fig.9 Travel time distribution (Public transport)

Table 8 Travel time of each hub (Public transport, Setting1: 2015)

\begin{tabular}{|c|l|r|r|c|}
\hline \multicolumn{2}{|c|}{ No. / Abbreviated name } & $\begin{array}{c}\text { User population } \\
\text { (Persons) }\end{array}$ & $\begin{array}{c}\text { Average travel time } \\
(\mathrm{min})\end{array}$ & $\begin{array}{c}\text { Maximum travel time } \\
(\mathrm{min})\end{array}$ \\
\hline 1 & City center & 265,155 & 10.3 & 76.9 \\
\hline 2 & Toyosato & 18,429 & 20.1 & 62.4 \\
\hline 3 & Kamikawachi & 15,527 & 31.6 & 86.5 \\
\hline 4 & Okamoto & 23,376 & 17.5 & 52.8 \\
\hline 5 & Shopping Center-mae & 7,754 & 7.0 & 14.6 \\
\hline 6 & Hiraishi & 4,420 & 15.1 & 26.8 \\
\hline 7 & Technopolis & 18,178 & 19.1 & 52.5 \\
\hline 8 & Mizuhono & 14,084 & 15.8 & 55.8 \\
\hline 9 & Yokokawa & 7,042 & 15.7 & 34.9 \\
\hline 10 & Suzumenomiya & 48,413 & 15.8 & 46.5 \\
\hline 11 & Minami-utsunomiya & 4,897 & 8.8 & 20.8 \\
\hline 12 & Esojima & 28,631 & 12.9 & 54.2 \\
\hline 13 & Nishikawata & 18,876 & 16.5 & 56.7 \\
\hline 14 & Shiroyama & 18,681 & 16.8 & 95.8 \\
\hline 15 & Kunimoto & 14,988 & 13.9 & 52.0 \\
\hline 16 & Tomiya & 7,850 & 17.4 & 67.0 \\
\hline 17 & Shinoi & 2,294 & 14.2 & 76.1 \\
\hline \multicolumn{2}{|c|}{ All } & 518,594 & 13.4 & 95.8 \\
\hline
\end{tabular}

Low value in a column High value in a column

Table 9 Effect of the induction (Public transport)

\begin{tabular}{|c|l|r|r|c|}
\hline \multicolumn{2}{|c|}{ No. / Abbreviated name } & $\begin{array}{c}\text { User population, } \\
\text { Setting2: } 2040 \\
\text { (Persons) }\end{array}$ & Average travel time, & $\begin{array}{c}\text { Ratio of change of } \\
\text { average travel time } \\
\text { (setting1: 2015 and } \\
\text { setting2: 2040) }\end{array}$ \\
\hline 1 & City center & 220,498 & 10.0 & -0.83 \\
\hline 2 & Toyosato & 13,678 & 19.7 & -2.05 \\
\hline 3 & Kamikawachi & 12,280 & 32.7 & 3.31 \\
\hline 4 & Okamoto & 19,237 & 17.2 & -1.78 \\
\hline 5 & Shopping Center-mae & 6,929 & 7.1 & 0.84 \\
\hline 6 & Hiraishi & 3,476 & 15.1 & 0.39 \\
\hline 7 & Technopolis & 12,618 & 20.0 & 4.67 \\
\hline 8 & Mizuhono & 11,249 & 15.2 & -3.56 \\
\hline 9 & Yokokawa & 6,297 & 17.0 & 8.10 \\
\hline 10 & Suzumenomiya & 38,597 & 15.3 & -1.21 \\
\hline 11 & Minami-utsunomiya & 3,771 & 8.8 & -0.16 \\
\hline 12 & Esojima & 23,112 & 12.8 & -0.98 \\
\hline 13 & Nishikawata & 15,461 & 16.3 & -1.59 \\
\hline 14 & Shiroyama & 15,421 & 16.3 & -5.06 \\
\hline 15 & Kunimoto & 12,300 & 14.1 & -0.29 \\
\hline 16 & Tomiya & 6,521 & 17.4 & 0.14 \\
\hline 17 & Shinoi & 1,757 & 13.5 & -4.82 \\
\hline & All & 423,203 & 13.3 & -1.32 \\
\hline
\end{tabular}

Low value in a column High value in a column 


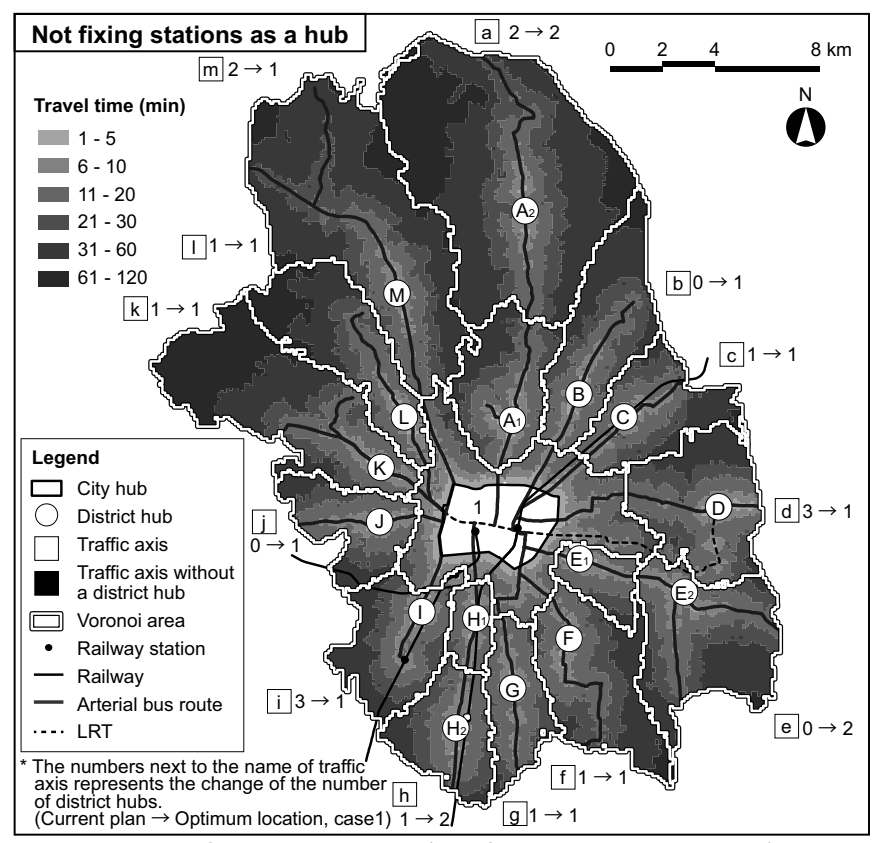

Fig.10 Optimum location (Not fixing stations as a hub)

Table 10 Travel time of each hub (Not fixing stations as a hub)

\begin{tabular}{|c|l|c|c|c|}
\hline \multicolumn{2}{|c|}{ No. / Traffic axis } & $\begin{array}{c}\text { User population, } \\
\text { Setting1: 2015 } \\
\text { (Persons) }\end{array}$ & $\begin{array}{c}\text { Average travel time, } \\
\text { Setting1: 2015 (min) }\end{array}$ & $\begin{array}{c}\text { Maximum travel time } \\
\text { (min) }\end{array}$ \\
\hline 1 & All traffic axes & 187,175 & 6.1 & 40.0 \\
\hline$A_{1}$ & a (Bus) & 16,273 & 18.3 & 53.0 \\
\hline$A_{2}$ & a (Bus) & 17,230 & 31.9 & 95.8 \\
\hline B & b (Bus) & 23,546 & 16.3 & 59.5 \\
\hline C & c (Railway, Bus) & 19,193 & 15.8 & 52.8 \\
\hline D & d (LRT, Bus) & 17,660 & 17.2 & 52.5 \\
\hline E $_{1}$ & e (Bus) & 19,583 & 11.2 & 43.1 \\
\hline E $_{2}$ & e (Bus) & 11,763 & 17.9 & 58.7 \\
\hline F & f (Bus) & 21,507 & 15.8 & 61.5 \\
\hline G & g (Bus) & 6,831 & 15.1 & 35.9 \\
\hline H 1 & h (Bus) & 13,821 & 11.0 & 32.0 \\
\hline$H_{2}$ & h (Railway, Bus) & 44,341 & 16.2 & 47.1 \\
\hline I & i (Railway, Bus) & 48,670 & 14.6 & 59.2 \\
\hline J & j (Bus) & 15,105 & 13.6 & 50.6 \\
\hline K & k (Bus) & 22,382 & 14.6 & 100.3 \\
\hline L & I (Bus) & 22,209 & 12.2 & 58.2 \\
\hline M & m (Bus) & 11,303 & 17.7 & 84.5 \\
\hline & \multicolumn{1}{|c|}{ All } & 518,594 & 12.4 & 100.3 \\
\hline
\end{tabular}

Low value in a column High value in a column

\section{5. 結論}

本研究では交通軸上での拠点配置について、公共交通機関利用を 想定し、拠点への移動時間分布を算出し、移動時間最小化に基づく 地域拠点の最適配置を示した。得られた知見は、以下の 3 点である。 （1）現行計画の拠点配置では、拠点別の利用圈域内人口に大きな差 があるなど、移動時間の観点から拠点間の不均衡がみられたことか ら、地域拠点の一律な整備には注意が必要である。

（2）現行計画では拠点や公共交通機関の沿線への居住誘導が計画さ れているが、本研究の結果から、拠点配置を最適化した方が都市内 の平均移動時間に対して効果が大きいことが確認された。さらに、 最適配置に居住誘導を組み合わせることで、それらは顕著になる。

(3) 最適配置の結果から、現行計画の地域拠点について、16 拠点の うち 6 拠点は、拠点位置の妥当性の高さが示された。また、拠点別 の利用圈域内人口の分散が抑えられ、移動時間に観点から拠点間の 不均衡が是正された。

一方、今後の課題として以下が挙げられる。本研究では、都市拠

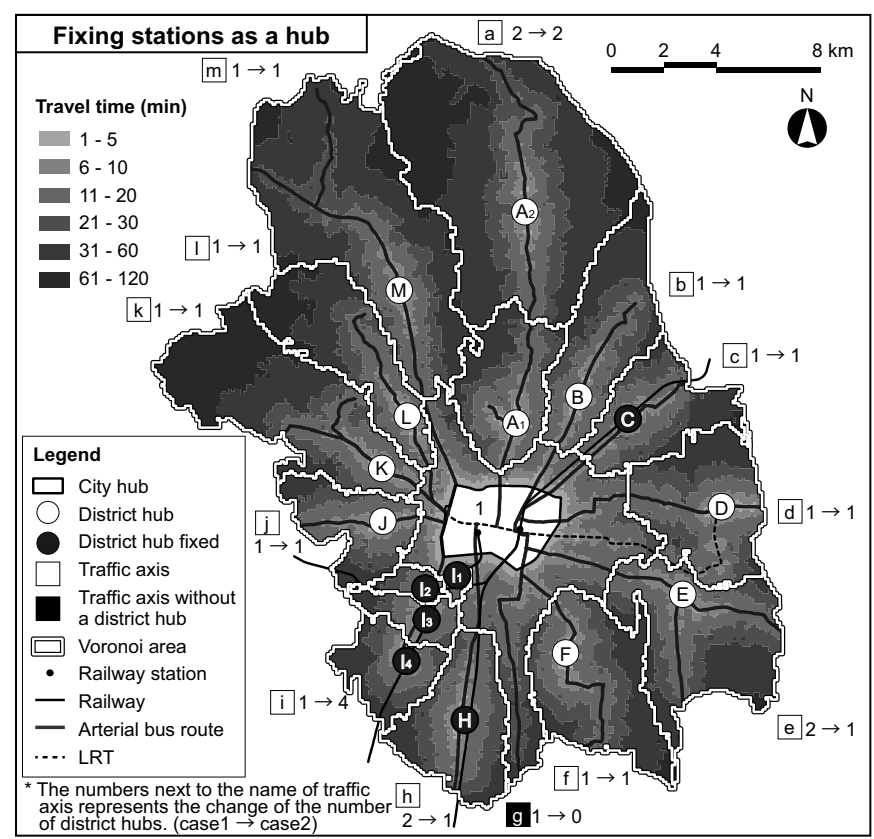

Fig.11 Optimum location (Fixing stations as a hub)

Table 11 Travel time of each hub (Fixing stations as a hub)

\begin{tabular}{|c|l|c|c|c|}
\hline \multicolumn{2}{|c|}{ No. / Traffic axis } & $\begin{array}{c}\text { User population, } \\
\text { Setting1: } 2015 \\
\text { (Persons) }\end{array}$ & $\begin{array}{c}\text { Average travel time, } \\
\text { Setting1: } 2015(\mathrm{~min})\end{array}$ & $\begin{array}{c}\text { Maximum travel time } \\
\text { (min) }\end{array}$ \\
\hline 1 & All traffic axes & 209,548 & 7.3 & 41.3 \\
\hline A $_{1}$ & a (Bus) & 16,273 & 18.3 & 53.0 \\
\hline A $_{2}$ & a (Bus) & 17,230 & 31.9 & 95.8 \\
\hline B & b (Bus) & 23,546 & 16.3 & 59.5 \\
\hline C & c (Railway, Bus) & 19,193 & 15.8 & 52.8 \\
\hline D & d (LRT, Bus) & 17,660 & 17.2 & 52.5 \\
\hline E & e (Bus) & 14,107 & 18.1 & 58.7 \\
\hline F & f (Bus) & 22,533 & 16.9 & 59.9 \\
\hline H & h (Railway, Bus) & 49,094 & 16.0 & 46.5 \\
\hline I1 & i (Railway, Bus) & 4,602 & 8.4 & 20.8 \\
\hline I & i (Railway, Bus) & 10,913 & 12.1 & 50.4 \\
\hline I 3 & i (Railway, Bus) & 23,905 & 12.7 & 45.2 \\
\hline I4 & i (Railway, Bus) & 19,072 & 16.5 & 56.7 \\
\hline J & j (Bus) & 15,024 & 13.5 & 49.4 \\
\hline K & k (Bus) & 22,382 & 14.6 & 100.3 \\
\hline L & I (Bus) & 22,209 & 12.2 & 58.2 \\
\hline M & m (Bus) & 11,303 & 17.7 & 84.5 \\
\hline & \multicolumn{1}{|c|}{ All } & 518,594 & 12.7 & 100.3 \\
\hline
\end{tabular}

Low value in a column High value in a column

点から放射状に整備された交通軸の利用を想定しているが、環状道 路などを含めた新たな公共交通路線の選択を分析に考慮することで、 拠点配置や利便性が大きく変わると考えられる。加えて、自家用車 利用を組み合わせたパークアンドライド等の交通施策 ${ }^{30)}$ も加味し、 徒歩と公共交通機関利用以外の組合せについても今後考慮する必要 がある。また、移動について、本研究では文献から参照可能な移動 速度を公共交通機関種別ごとに設定しているが、種別ごとの特性（運 行頻度、運賃）は考慮できていない。移動距離をもとにした物理的 な移動時間のみならず、種別ごとの特性を考慮することでより分析 の精度を上げることができると考えられる。さらに、本研究では、 現行計画において各地域拠点の誘導施設に、高次都市機能を除くす べての分野の施設が設定されていることから、すべての地域拠点で の一律な整備を想定した。さらに、公共交通機関によるネットワー ク形成を想定しているが、都市部／都市部以外の地域が混在する地 方都市において、想定されるべき地域構造のあり方にはさらなる検 討が必要である。特に、拠点ごとの需要に適した機能と規模の設定、 


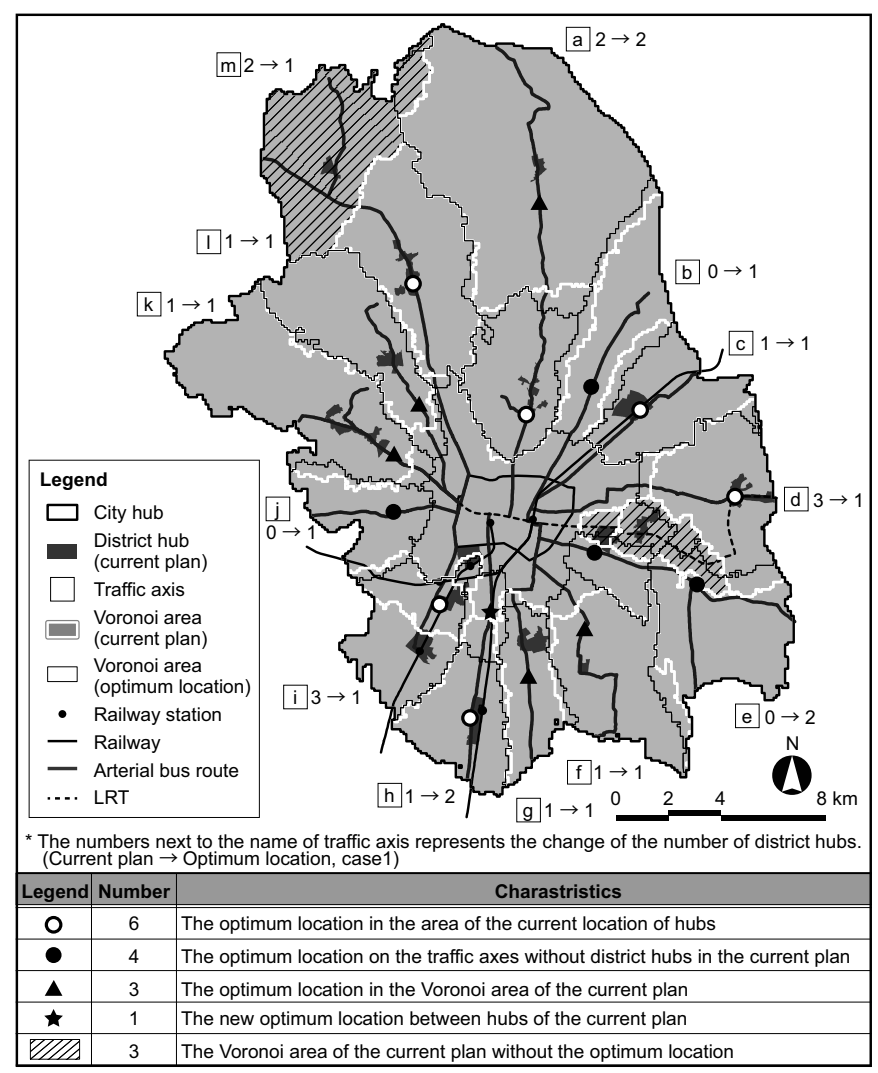

Fig.12 Comparison of the current plan and the optimization

拠点間の機能補完、階層的な拠点の設定等が必要になると考えられ、 これらの課題に対応した拠点配置手法の構築を今後進めていく。

\section{謝辞}

本研究は文部科学省科学研究費補助金基盤研究（B）「地域条件に よるサービス提供限界導出に基づく医療・介護連携の最適提供モデ ルの構築」(課題番号：18H03020、研究代表者：佐藤栄治）の一環と して行われた。また、本研究を進めるにあたり、データの提供をい ただいた宇都宮市役所のみなさまをはじめとし、さまざまな方にご 協力をいただいた。ここに記して謝意を表する。

\section{注}

注 1）表 1 に示寸 16 地区ごとの土地利用は、平成 28（2016）年度宇都宮市都 市計画基礎調査より集計した。「建物用地」は住宅用地、商業用地、「農用地」 は田、畑、「自然系土地利用」は山林、水面を集計した。

注 2）市から 2017 年 8 月時点の区域データ（素案）を入手し、分析に使用した。 立地適正化計画において南宇都宮駅周辺エリア、LRT 停留所周辺エリアの 2 拠点は都市拠点圈域とされているが、本研究では都市拠点と分離された地域 拠点として分析する。

注 3）宇都宮市立地適正化計画では、交通軸に加え、支線および地域内交通を 提供する地域をエリアで示し、以上の 2 点を交通ネットワークとしている。

注 4）なお、交通軸以外の公共交通機関（支線となるバス路線等）については、 居住誘導区域の設定基準とされず、同計画内では路線ではなくエリアのみの 指定である。加えて、今後の経済状況、地域別の高齢者施策等で変動する可 能性が高いことなどから、本研究では考慮していない。これらを考慮した場 合、拠点への移動時間や、最適配置について、異なる結果を得ると考えられる。 注 5）二本の道路縁から中心線を作成したリンクとノードから成る道路ネット ワークデータであるため、歩道、歩道橋、地下通路は考慮していない。

注 6) 本研究では、 5 年ごとの将来推計人口值から居住誘導による人口増減を 推定するため、直近の将来人口である 2020 年からの居住誘導を想定した。 ただし、立地適正化計画の策定は 2017 年 3 月であるが、居住誘導区域は
2019 年 3 月の改定によって発表された。

注 7）市の意向を反映し ${ }^{36)}$ 、各 16 地区内において居住誘導が実施される想定 によって推定した。

注 8）地域拠点として指定されていない他の 1 駅についても今後拠点の指定が 検討されている ${ }^{24)}$ 。

\section{参考文献}

1) Asami, Y. (ed.): Residential Environment: Evaluation Method and Application, University of Tokyo Press, 2001 (in Japanese)

浅見泰司（編）：住環境：評価方法と理論, 東京大学出版会, 2001

2) National Institute of Population and Social Security Research: Population Projections for Japan (2017), 2017.7 (in Japanese)

国立社会保障 - 人口問題研究所：日本の将来推計人口（平成 29 年推計）, 2017. 7

3) Ministry of Land, Infrastructure, Transport and Tourism: Grand Design of National Spatial Development towards 2050, Japan, 2014.7

国土交通省：国土のグランドデザイン 2050 ～対流促進型国土の形成 $\sim$, 2014. 7

4) City Planning Division, City Bureau, Ministry of Land, Infrastructure, Transport and Tourism: Evaluation handbook of urban structure, 2014.8 (in Japanese)

国土交通省都市局都市計画課：都市構造の評価に関するハンドブック， 2014.8

5) Syakaishihonseibishingikai Toshikeikakubukai Chushinshigaichisaisei Syouiinkai (Subcommittee for Revitalization of the City Center, Urban planning committee, The Panel on Infrastructure Development), Chushinshigaichisaisei Syouiinkai Houkoku (Report of Subcommittee for Revitalization of the City Center), 2006.1 (in Japanese)

社会資本整備審議会都市計画部会中心市街地再生小委員会：中心市街地再生 小委員会報告, 2006.1

6) Nakai, T.: Konpakutoshithi No Rinen To Seidotekiwakugumi (The Concept and the Institutional Framework in Compact City), 2017 Nendo Nihonkenchikugakkaitaikai Tosikeikakubumon Kenkyukyougikai Siryou (Materials of urban planning research committee of Annual Convention Architectural Institute of Japan 2017), pp.1-7, 2017.9 (in Japanese) 中井検裕：コンパクトシティの理念と制度的枠組み, 2017 年度日本建築学 会大会都市計画部門研究協議会資料，pp. 1-7，2017.9

7) Ministry of Land, Infrastructure, Transport and Tourism: Ricchitekiseikakeikakusakusei No Torikumijoukyou (Setting condition of location normalization plan), http://www.mlit.go.jp/toshi/city_plan/toshi_ city_plan_fr_000051.html (accessed 2019-05-01)

国土交通省：立地適正化計画作成の取組状況, http://www. mlit.go.jp/ toshi/city_plan/toshi_city_plan_fr_000051.html, 最終参照 2019.5.1

8) Ministry of Land, Infrastructure, Transport and Tourism: Urban Planning Procedural Guidelines: 10th Edition, http://www.mlit.go.jp/toshi/ city_plan/crd_city_plan_fr_000008.html (accessed 2019-05-01)

国土交通省：都市計画運用指針 第 10 版（平成 30 年 11 月 16 日一部改正）, http://www. mlit.go.jp/toshi/city_plan/crd_city_plan_fr_000008.html, 最終参照 2019.5.1

9) Hori, Y., A.Hosomi and T.Kurokawa: Study on the Effects on Energy Consumption by Vehicle Trips in a Compact City, Journal of the City Planning Institute of Japan, Vol.34, pp.241-246, 1999 (in Japanese)

堀裕人, 細見昭, 黒川洸: 自動車エネルギー消費量から見たコンパクト シティーに関する研究, 日本都市計画学会学術研究論文集, 第 34 巻, pp. 241-246, 1999

10) Morimoto, A.: The Effect of Shrinking City on Local Government Finance and Global Environment, Journal of the City Planning Institute of Japan, Vol.46, No.3, pp.739-744, 2011.10 (in Japanese) 森本章倫：都市のコンパクト化が財政及び環境に与える影響に関する研究, 都市計画論文集，第 46 巻，第 3 号, pp. 739-744, 2011. 10

11) Higo, Y., H.Mori, and M.Taniguchi: Change from "Concentrating in core areas" to "Refining core areas", Journal of the City Planning Institute of Japan, Vol.49, No.3, pp.921-926, 2014.10 (in Japanese)

肥後洋平, 森英高, 谷口守：「拠点一集約」から「拠点を集約」へ，都市 計画論文集，第 49 巻，第 3 号，pp. 921-926, 2014.10

12) Suzuki, T.: A Study on Optimal 3D Urban Form from a Viewpoint of Compactness, Journal of the City Planning Institute of Japan, Vol.28, 
pp.415-420, 1993 (in Japanese)

鈴木勉：コンパクトな立体都市空間形態に関する考察， 日本都市計画学会 学術研究論文集, 第 28 巻, pp. 415-420, 1993

13) Koshizuka, T.: Compact Proportion of a City with Respect to Travel Time, Journal of the City Planning Institute of Japan, Vol.30, pp.499-504, 1995 (in Japanese)

腰塚武志 : コンパクトな都市のプロポーション, 日本都市計画学会学術研 究論文集，第 30 巻, pp. 499-504, 1995

14) Kondo, T. and T.Yoshikawa: Optimum Three-Dimensional Urban Form Containing Compact City System, Journal of Architecture and Planning (Transactions of AIJ), Vol.79, No.703, pp.1923-1931, 2014.9 (in Japanese) 近藤赴弘, 吉川徹：コンパクトシティ・システムを内包する 3 次元都市形態, 日本建築学会計画系論文集, 第 79 巻, 第 703 号, pp. 1923-1931, 2014.9

15) Suzuki, T.: Mathematical Programing Modeling for Optimal Urban Structure Focusing on Combination of Hubs and Axes, Journal of the City Planning Institute of Japan, Vol.53, No.3, pp.1472-1477, 2018.10 (in Japanese)

鈴木勉：拠点と軸の組合せに着目した都市構造の数理最適化，都市計画論 文集，第 53 巻，第 3 号，pp. 1472-1477, 2018. 10

16) Tsuboi, S., S.Ikaruga, T.Kobayashi and S.Nishimura: A Study on the Visualization and Evaluation Method of Compact City based on Expert System, Journal of Architecture and Planning (Transactions of AIJ), Vol.82, No.731, pp.105-114, 2017.1 (in Japanese)

坪井志郎, 鵤心治, 小林剛士, 西村祥：エキスパートシステムによる集約 型都市構造の可視化と評価手法に関する研究, 日本建築学会計画系論文集, 第 82 巻，第 731 号, pp. 105-114, 2017.1

17) Suzuki, T.: Optimum Locational Patterns of Bus-Stops for Many-to-One Travel Demand, Journal of the City Planning Institute of Japan, Vol.22, pp.247-252, 1987 (in Japanese)

鈴木勉：通勤バス路線上の停留所の最適配置, 日本都市計画学会学術研究 論文集，第 22 巻, pp. 247-252, 1987

18) LE Phong Nguyen and T.Yoshikawa: A Method for Quantitative Evaluation of Urban Pedestrians Accessibility by Public Transport, Journal of Architecture and Planning (Transactions of AIJ), Vol.81, No.725, pp.1579-1588, 2016.7 (in Japanese)

レフォングェン, 吉川徹：公共交通機関を考慮した歩行者の都市内アク セシビリティの定量的評価手法, 日本建築学会計画系論文集, 第 81 巻, 第 725 号, pp. 1579-1588, 2016.7

19) Utsunomiya City: Nettowa-kugatakonpakutoshithi Keisei Bijon (Vision of the Formation of Network-type Compact City), 2015.2 (in Japanese) 宇都宮市：ネットワーク型コンパクトシティ形成ビジョン, 2015.2

20) Utsunomiya City: Utsunomiyashi Jinkou Bijon (Population Vision of Utsunomiya City), p.20, 2015.10 (in Japanese)

宇都宮市：宇都宮市人口ビジョン, p. 20, 2015.10

21) Utsunomiya City: Utsunomiya No Chikugyousei Ni Tsuite (About Utsunomiya's administrative section), https://www.city.utsunomiya. tochigi.jp/shisei/machi/chikugyousei/1009224.html (accessed 2019-06-12) 宇都宮市：宇都宮の地区行政について, https://www. city. utsunomiya. tochigi.jp/shisei/machi/chikugyousei/1009224.html, 最終参照 2019.6. 12

22) Utsunomiyashi Toukei De-tabanku (Utsunomiya City statistical databank): Utsunomiyashi 16 Chiku Ichizu (Utsunomiya City 16 districts diagram), http://www2.city.utsunomiya.tochigi.jp/DataBank/main_8.htm (accessed 2019-06-12)

宇都宮市統計データバンク：宇都宮市 16 地区 位置図, http : / www2. city. utsunomiya. tochigi.jp/DataBank/main_8.htm，最終参照 2019.6. 12

23) Utsunomiya City: Dai 5 Ji Utsunomiyashi Sougoukeikaku (The 5th Utsunomiya City Comprehensive Plan), 2008.3 (in Japanese)

宇都宮市：第 5 次宇都宮市総合計画, 2008. 3

24) Utsunomiya City: Location Normalization Plan of Utsunomiya City (formulated on March, 2017), http://www.city.utsunomiya.tochigi.jp/shisei/ machizukuri/1014948/1009282.html (accessed 2019-01-28)

宇都宮市：宇都宮市立地適正化計画（平成 29 年 3 月策定）, http://ww. city. utsunomiya. tochigi. jp/shisei/machizukuri/1014948/1009282. html, 最終参照 2019.1.28

25) Utsunomiya City: Shigaikatyouseikuiki No Seibi Oyobi Hozen No Houshin (Policy of Maintenance and Preservation in Urbanization Control
Areas), 2018.3 (in Japanese)

宇都宮市：市街化調整区域の整備及び保全の方針，2018.3

26) NAVITIME JAPAN Co., Ltd.: Chizu Ru-to Kensaku (Maps and Root retrieval), http://www.navitime.co.jp (accessed 2018-12-13) 株式会社ナビタイムジャパン：地図・ルート検索, http://www. navitime. co.jp，最終参照 2018.12.13

27) Hirabayashi, H.: GPS De-ta Wo Mochiita Ekitanmatsubasu No Sokudoteikayouin No Bunseki (Analysis of Decreased Speed of Railfeeder Bus based on GPS data), Shibaura kogyo daigaku kogakubu dobokukougakuka sotsugyouronbun kougai (Summaries of graduation theses of Department of Civil Engineering, College of Engineering, Shibaura Institute of Technology), 2006 (in Japanese)

平林英樹：GPS データを用いた駅端末バスの速度低下要因の分析, 芝浦工業 大学工学部土木工学科卒業論文梗概, 2006

28) Utsunomiya City: Dai 12 Kai Haga Utsunomiya Kikankoukyoukoutsu Kentouiinkai Shiryou1 Haga Utsunomiya LRT No Syaryou Ni Tsuite (The 12th investigation committee for Haga and Utsunomiya basic public transportation: Document1 About Haga and Utsunomiya LRT vehicles), https://www.city.utsunomiya.tochigi.jp/kurashi/kotsu/lrt/1006078.html (accessed 2018-12-01)

宇都宮市：第 12 回「芳賀 - 宇都宮基幹公共交通検討委員会」資料 1 芳賀 · 宇都宮 LRT の車両について, https://www. city. utsunomiya. tochigi.jp/ kurashi/kotsu/lrt/1006078. html, 最終参照 2018.12.1

29) Okuaki, K.: Method to Generate the Linedata of the Road Centerline Automatically along with the Attribute Data of Width of Road, Papers and proceedings of the Geographic Information Systems Association, Vol.21, pp.1-4, 2012 (in Japanese)

奥秋恵子：道路形状ポリゴンを用いた、道路幅員ネットワークデータの自動 生成, 地理情報システム学会講演論文集, Vol.21, pp. 1-4, 2012

30) Utsunomiya City: Haga Utsunomiya Tobuchiiki Koukyoukoutsuumou Keiseikeikaku (Regional Public Transport Reorganization Plan of Haga and the eastern part of Utsunomiya), 2015.11 (in Japanese)

宇都宮市：芳賀・宇都宮東部地域公共交通網形成計画, 2015. 11

31) Utsunomiya City: Utsunomiya Haga Basurosen Mappu (Bus route map of Utsunomiya and Haga), http://www.city.utsunomiya.tochigi.jp/kurashi/ kotsu/kokyo/1006057.html (accessed 2018-12-01)

宇都宮市：宇都宮・芳賀バス路線マップ, http://www. city. utsunomiya. tochigi. jp/kurashi/kotsu/kokyo/1006057.html, 最終参照 2018. 12.1

32) Inoue, T.: The Web System of Small Area Population Projections for the Whole Japan, http://arcg.is/1LqC6qN (accessed 2018-12-01)

井上孝：全国小地域別将来人口推計システム, http://arcg. is/1LqC6qN, 2018. 12. 1 参照

33) National Institute of Population and Social Security Research: Regional Population Projection for Japan: 2010-2040 (March 2013), http://www. ipss.go.jp/pp-shicyoson/j/shicyoson13/t-page.asp (accessed 2018-12-01)

国立社会保障・人口問題研究所：日本の地域別将来推計人口（平成 25 年 3 月推計）, http://www. ipss. go. jp/pp-shicyoson/j/shicyoson13/t-page. asp, 2018. 12.1 参照

34) Hansen,P., M.Labbe, D.Peeters and J.-F.Thisse: Facility Location Analysis, Systems of Cities and Facility Locatioon.Chur,Hawood Academic Press, pp.1-70, 1987

35) Ugajin, T., E.Satoh, T.Suzuki and N.Mitsuhashi: A Study on the Optimum Location of Fire Departments based on the Actual Data of Fire Bureau, AIJ Journal of Technology and Design, Vol.23, No.53, pp.241-246, 2017.2 (in Japanese)

宇賀神直彬, 佐藤栄治, 鈴木達也, 三橋伸夫：救急・消防の実働データか ら見た消防署の適正配置検討に関寸る研究, 日本建築学会技術報告集, 第 23 巻, 第 53 号, pp. 241-246, 2017.2

36) Ito, Y.: Utsunomiyashiniokeru Syouraijinnkousuikei To Nettowakugatakonpakutoshithi Keisei Ni Muketa Chiiki No Kadai Ni Kansuru Kenkyu (Research on Population Projections and Regional Issues for the formation of Network-type Compact City in Utsunomiya City), Shisei Kenkyu Utsunomiya (Civic Research Utsunomiya), Vol.14, pp.15-24, 2018.3 (in Japanese)

伊藤悠紀子, 宇都宮市における将来人口推計とネットワーク型コンパクトシ ティ形成に向けた地域の課題に関する調査研究, 市政研究うつのみや, 第 14 号, pp. 15-24, 2018. 3 


\title{
A PROPOSAL FOR THE OPTIMUM LOCATION OF HUBS BY MINIMIZING TRAVEL TIME WITH MAIN PUBLIC TRANSPORT USAGE
}

\author{
Ryo SHIMAMURA *1, Eiji SATOH ${ }^{* 2}$, Tatsuya SUZUKI ${ }^{* 3}$ \\ and Yasuhiro NOHARA*4 \\ ${ }^{* 1}$ Doctor's Degree Course, Graduate School of Eng., Utsunomiya Univ., M.Eng. \\ ${ }^{* 2}$ Assoc. Prof., Faculty of Regional Design, Utsunomiya Univ., Dr.Eng. \\ ${ }^{* 3}$ Research Assoc., Center for Community Medicine, Jichi Medical Univ., Dr.Eng. \\ ${ }^{*}$ Project Research Assoc., Center for Regional Design, Utsunomiya Univ., Dr.Eng.
}

In provincial cities of Japan that have formed an urban structure dependent on automobile traffics, the difficulty in sustainable accessibility to urban functions is unavoidable with the declining population and aging society. As a solution to such a situation, there has been an effort to promote the change of an urban structure by combination of hubs and public transport's traffic axes though implementing a compact city policy. The operation of city/district hubs is units of several public services such as medical services, welfare services, shopping for daily necessities. However, it lacks the objective and quantitative basis of accessibility to a city/district hub in current location plans of numerous cities. Therefore, we focused on residents' travel time to a hub. The purpose of this study is to reveal the optimum location of district hubs by minimizing the sum of resident's travel time with public transport usage in the study city.

The research target city designated one city hub and 16 district hubs, and the public transport between the hubs in March 2017. In addition, there has been the effort to promote the residential induction in the areas around them. In this paper, we defined traveling time to the nearest hub as travel cost. First of all, we analyzed the accessibility to a hub of the current plan. In this analysis, current hub's effective areas were calculated based on minimize their travel time that combined walking time and boarding time of public transport usage. In order to clarify the effect of the residence-guided plan, the analysis was based on the population distribution of two settings such as current population, future population. As a result, the imbalance about the user populations of each hub in the current plan were grasped. The difference of the number of user populations between the most and the least population was more than 20 times. In addition, the large improvement of the accessibility to a hub by the residential move was not demonstrated.

Next, the optimum location of 16 district hubs was calculated by the p-median problem. The candidates of district hubs are 305 stops of the public transport. Then, the optimization was calculated by two patterns: Not fixing stations as a hub, fixing stations as a hub. In the case of not fixing stations as a hub, the average of resident's travel time decreased by $7.4 \%$ the optimization compared with that of the current plan. On the other hand, the optimization of fixing stations as a hub was not effective on the accessibility to a hub.

Finally, the optimum location was compared with the current plan's location. As a result, more than a third of the optimum location were overlapped with the hub area of the current plan were revealed that the validity as a district hub in the current plan. In addition, the optimum location distributed to all traffic axes.

The conclusions are as follows.

1) The imbalance about the user populations of each hub was revealed in the current plan. Therefore, the formation of uniform hubs by the current plan requires attention.

2) The large improvement of the accessibility to a hub by the residential move plan was not demonstrated.

3) The validity in location of 6 out of 16 district hubs in the current plan was demonstrated in a quantitative way. 